\title{
Biochemical characterisation of human isolates of Blastocystis hominis
}

\author{
N. S. MANSOUR, E. M. MIKHAIL, N. A. EL MASRY, A. G. SABRY and E. W. MOHAREB
}

US Naval Medical Research Unit No. 3, Cairo, Egypt

\begin{abstract}
Summary. SDS-PAGE and iso-enzyme analysis of 11 human isolates of Blastocystis hominis revealed at least two variants with different polypeptide patterns and two zymodemes, respectively. This is the first iso-enzyme and the second protein analysis to indicate strain differences in $B$. hominis.
\end{abstract}

\section{Introduction}

Blastocystis hominis is a common protozoan found in the human intestinal tract. It has diversity of shape and size, of which the four distinct forms are recognised: vacular (central body, CB), amoeboid, granular and multiple fission. The last three forms can be derived only from the $\mathrm{CB}$ form. ${ }^{1}$ The pure amoeboid form seen in rare cases of blastocystosis with very severe symptoms reverts to the typical CB form in culture and in vivo, when symptoms subside. ${ }^{2} \mathrm{~A}$ relationship to Apicomplexa and Sarcodina has been suggested ${ }^{2}$ but the amoeboid form lacks certain characteristics of these genera. For these reasons Jiang and $\mathrm{He}^{1}$ suggested a separate classification and assigned the parasite to the subphylum blastocysta. Conversely, Boreham and Stenzel ${ }^{3}$ felt that $B$. hominis did not fit into existing protozoan classifications and Hollebeke and Mayberry ${ }^{4}$ recommended that Blastocystis remain incerta sedis until the taxon can be more adequately defined.

Morphologically similar $B$. hominis organisms have been detected in stools of both asymptomatic individuals $\mathrm{s}^{5-6}$ and patients with diarrhoea ${ }^{5-6}$ and other gastrointestinal symptoms. ${ }^{7-10}$ Such information led Kukoschke et al. ${ }^{5}$ to hypothesise that different types of $B$. hominis with the same morphology but with varying pathogenic potential might exist. Kukoschke and Müller ${ }^{11}$ supported this hypothesis by identifying at least two biochemically and immunologically distinct $B$. hominis strains from man. Moreover, Boreham et $a l .^{12}$ found that human isolates of $B$. hominis constitute at least two distinct groups, differing in their DNA

Received 13 April 1994; revised version accepted 31 Oct. 1994. ${ }^{*}$ Correspondence should be sent to Research Publications Branch, US Naval Medical Research Unit No. 3 (NAMRU-3), PSC 452 Box 5000, Code 101F, FPO AE 09835-0007, Cairo, Egypt. contents and their protein patterns. The present study was conducted to investigate the extent of the biochemical differences among human isolates of $B$. hominis and to determine if these differences relate to the pathogenic potential of the organism.

\section{Materials and methods}

Stool specimens from nine patients with gastrointestinal symptoms and two asymptomatic individuals were examined repeatedly (at least five times) for parasites by the Merthiolate-iodine-formaldehydeether concentration method ${ }^{13}$ and by the modified Ziehl Neelsen stain ${ }^{14}$ for Cryptosporidium. Stools were cultured routinely for pathogenic bacteria and tested serologically for rotavirus. The clinical and laboratory data were used to classify the cases into asymptomatic or symptomatic carriers and patients with acute or chronic gastrointestinal symptoms, according to the definitions of Doyle et al ${ }^{6}$

\section{Culture of $B$. hominis}

$B$. hominis organisms were isolated and grown axenically in a diphasic egg medium under anaerobic conditions as described by Zierdt. ${ }^{15}$

\section{Sample preparation}

Axenically grown $B$. hominis were pelleted by centrifugation at $4000 \mathrm{~g}$ for $10 \mathrm{~min}$ and the supernate from each isolate was saved as a control. The pellets were washed twice with phosphate-buffered saline (PBS), $\mathrm{pH} 7 \cdot 2$. Pellets were suspended in a minimum amount of distilled water and sonicated for $40 \mathrm{~s}$ with a Sonic 2000 Sonicator (Braun Melsungen, Germany). Protein concentrations of sonicates of $11 \mathrm{~B}$. hominis 
isolates were determined with the BioRad Protein Assay kit (BioRad, Richmond, CA, USA).

Each preparation was divided into two portions; one portion was used fresh for iso-enzyme analysis and the other was stored at $-20^{\circ} \mathrm{C}$ until used for protein analysis. The $11 \mathrm{~B}$. hominis isolates and their culture supernates were separated electrophoretically by SDSPAGE slab $^{16}$ (acrylamide $\left.12 \%\right)^{16}$ and on cellulose acetate membranes for glucose phosphate isomerase (GPI), phosphoglucomutase (PGM), malic enzyme (ME), 6-phosphogluconate dehydrogenase (6-PGD) and hexokinase (HK) iso-enzyme patterns following the method of Kreutzer and Christensen. ${ }^{17}$

\section{Results}

The $11 B$. hominis-infected persons comprised two asymptomatic carriers, four patients with acute diarrhoea (including two with salmonella enteritis and one with shigella dysentery) and five patients with chronic gastrointestinal symptoms (including one with giardiasis) (table).

Table. Relationship between the clinical presentation and the biochemical classification of $11 \mathrm{~B}$. hominis isolates

\begin{tabular}{|c|c|c|c|c|c|c|c|c|c|}
\hline \multirow{2}{*}{$\begin{array}{c}\text { Patient } \\
\text { no. }\end{array}$} & \multirow{2}{*}{$\begin{array}{c}\text { Faecal } \\
\text { parasites }\end{array}$} & \multirow{2}{*}{$\begin{array}{c}\text { Bacterial } \\
\text { pathogens }\end{array}$} & \multicolumn{5}{|c|}{$\begin{array}{l}\text { Clinical } \\
\text { signs and } \\
\text { symptoms }\end{array}$} & \multicolumn{2}{|c|}{$\begin{array}{l}\text { Biochemical } \\
\text { classification } \\
\text { of } B \text {. hominis }\end{array}$} \\
\hline & & & $\begin{array}{c}\text { Acute } \\
\text { diarrhoea }\end{array}$ & $\begin{array}{c}\text { Chronic } \\
\text { diarrhoea }\end{array}$ & $\begin{array}{c}\text { Constipation/ } \\
\text { diarrhoea }\end{array}$ & Colic & Flatulence & $\begin{array}{l}\text { Protein } \\
\text { variant }\end{array}$ & Zymodeme \\
\hline 1 & E. vermicularis & & & & & & & A & Z-I \\
\hline 2 & $\begin{array}{l}\text { E. coli } \\
\text { E. nana }\end{array}$ & & & & & & & B & Z-I \\
\hline 3 & S. mansoni & Shigella sp. & + & & & & & B & Z-I \\
\hline 4 & & & & + & & & + & B & Z-IIa \\
\hline 5 & & & & + & & & & B & Z-IIa \\
\hline 6 & G. lamblia & & & & & + & + & B & Z-IIa \\
\hline 7 & & & & & + & + & & B & Z-IIa \\
\hline 8 & & & & & & + & & $\bar{B}$ & Z-IIa \\
\hline 9 & & Salmonella sp. & + & & & & & B & Z-IIa \\
\hline 10 & & Salmonella sp. & + & & & & & B & Z-IIb \\
\hline 11 & & & + & & & & & B & Z-IIb \\
\hline
\end{tabular}

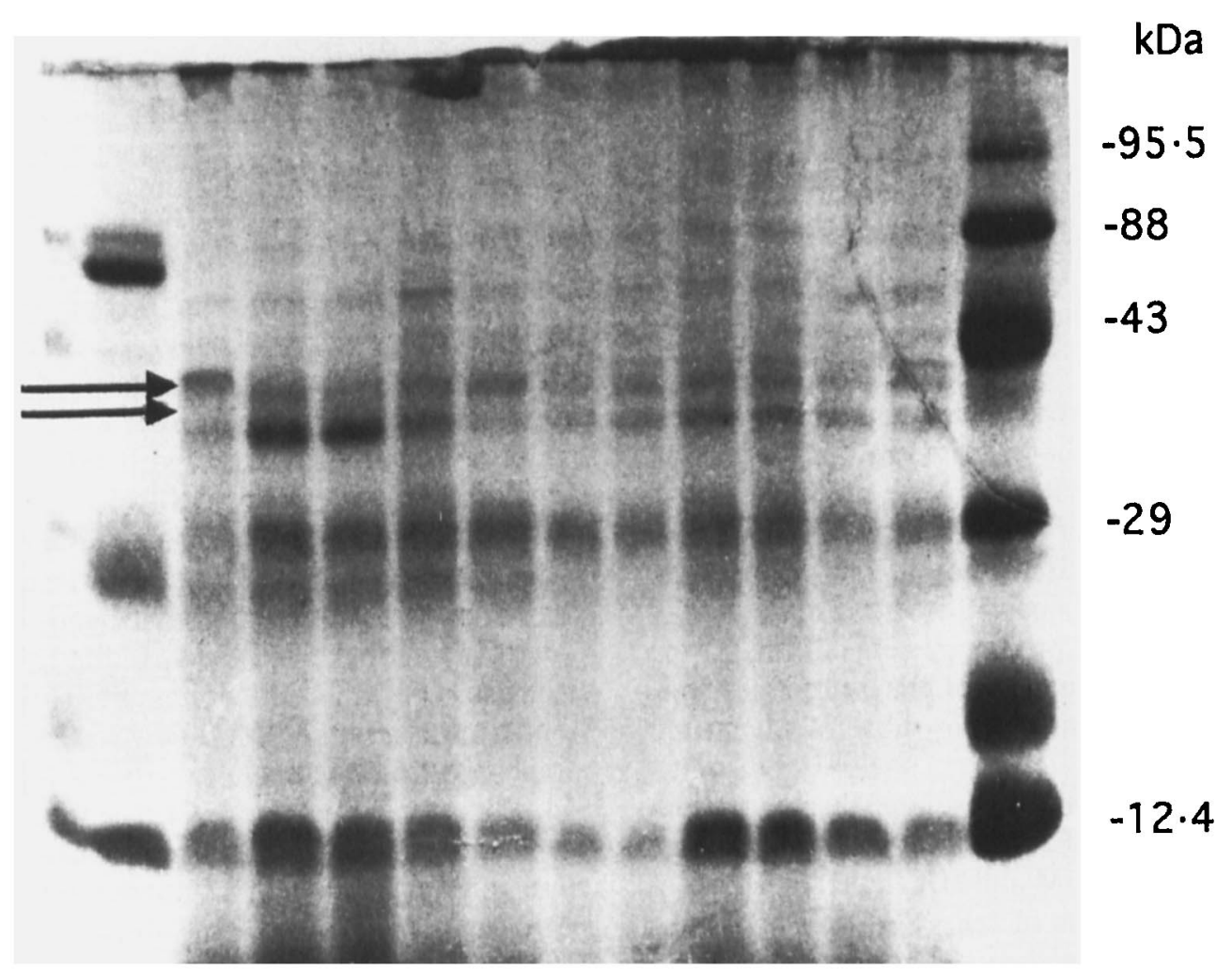

\section{$\begin{array}{llllllllllll}\mathrm{S} & 1 & 2 & 3 & 4 & 5 & 6 & 7 & 8 & 9 & 10 & 11\end{array}$}

Fig. 1. SDS-PAGE (12\% acrylamide) separation of total protein from axenic culture supernate (S) B. hominis isolates (1-11), and mol. wt markers. The arrows indicate significant differences between isolate no. 1 and the rest of the isolates. 
ME

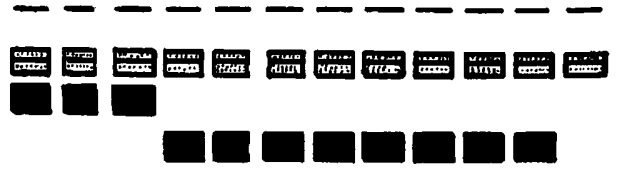

PGM
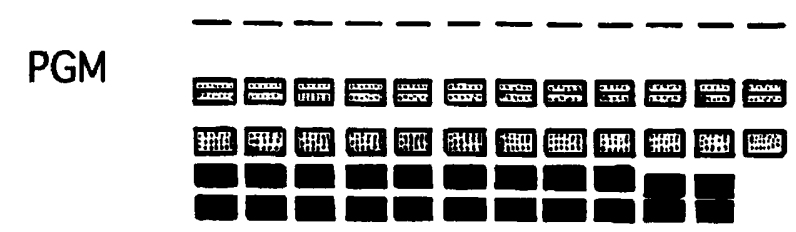

GPI

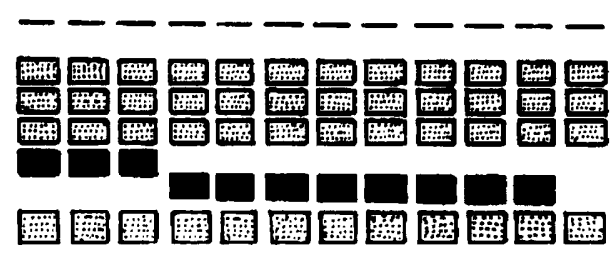

6PGD

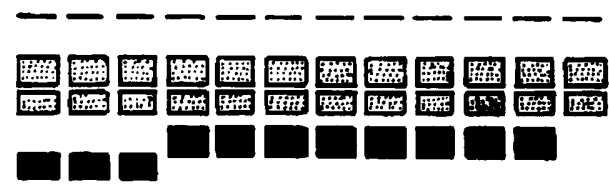

HK

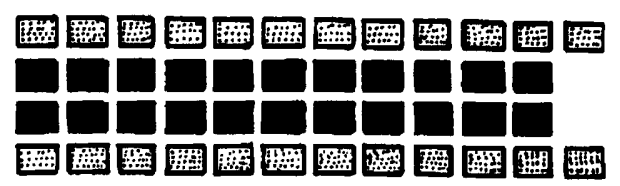

$\overline{1} \overline{2} \overline{3} \overline{4} \overline{5} \overline{6} \overline{7} \overline{8} \overline{9} \overline{10} \overline{11} \overline{\mathrm{s}}$

Fig. 2. Diagrammatic representation of malic enzyme (ME); phospholucomutase (PGM); glucose phosphate isomerase (GPI); 6-phosphogluconate dehydrogenase (6-PGD); hexokinase (HK) after electrophoresis on cellulose acetate membranes. Numbers 1-11 indicate $B$. hominis isolate number, $\mathrm{S}$, culture supernate.

The SDS-PAGE protein banding patterns of $B$. hominis isolates were characterised by common major protein bands of $12->95 \mathrm{kDa}$. The banding patterns were identical in 10 of the 11 isolates. The variant pattern in one isolate was characterised by the presence of an additional 40-kDa band and the absence of a 35$\mathrm{kDa}$ band (fig. 1). The protein patterns of the culture supernate (used as controls) of the 11 isolates were identical but were distinct from those of $B$. hominis organisms.

Iso-enzymes of $B$. hominis isolates resolved into a single dense band in ME, GPI and 6-PGD and double dense bands in both PGM and HK (fig. 2). Analysis of the iso-enzyme patterns of the 11 isolates generated two profiles which were classified as two zymodemes, designated as Z-I and Z-II (table). Z-I was represented by $B$. hominis from two asymptomatic carriers and one symptomatic carrier who also had shigellosis. Z-II was represented by $B$. hominis from eight symptomatic patients. It was characterised by a faster migrating band in 6-PGD and a slower migrating band in ME and GPI, compared with those of the three isolates designated as Z-I. B. hominis from the two symptomatic patients with acute diarrhoea belonging to ZII had a slower migrating band in one of the two PGM bands than the corresponding ones in the other nine isolates (fig. 2). The banding patterns of the five enzymes were identical in the culture supernates of the 11 isolates but were distinct from those of $B$. hominis isolates.

\section{Discussion}

In the present study, the protein profiles of the $11 B$. hominis isolates clearly demonstrated the existence of two variants, which were differentiated by the 35 - and $40-\mathrm{kDa}$ bands. One of the two variants was represented by $B$. hominis from nine symptomatic patients and one asymptomatic individual. These results differ from those of Kukosche and Müller ${ }^{7}$ who also found variants that differed in the $40-, 45-$ and $50-\mathrm{kDa}$ bands; one variant was isolated from two symptomatic patients and the other from an asymptomatic person and a patient suffering from diarrhoea. Furthermore, Boreham et al. ${ }^{12}$ examined $10 \mathrm{~B}$. hominis isolates and demonstrated two distinct groups differing in their protein and DNA contents, with significant differences between their genomes.

Iso-enzyme analysis, conducted for the first time on B. hominis, generated two zymodemes (Z-I and Z-II). Z-I included three isolates from the two asymptomatic patients and one patient with acute diarrhoea attributable to shigellosis. The other zymodeme (Z-II) included eight isolates, all from symptomatic patients (although two patients had proven salmonellosis). Furthermore, the latter zymodeme included two variants that were identical in their patterns of the five enzymes but differed in the migration of one of the two PGM bands. One of these variants (Z-IIa) included isolates from five patients with chronic gastrointestinal symptoms and one patient with salmonellosis. The other variant (Z-IIb) included two isolates associated with acute diarrhoea (table). The iso-enzyme analysis provided a better classification than the protein analysis of $B$. hominis from symptomatic and asymptomatic individuals. The five enzymes used in this study have been used previously to differentiate pathogenic from non-pathogenic strains of Entamoeba histolytica ${ }^{18}$ and vahlkamfiid amoebae. ${ }^{19}$

In the current study, mixed infections made it difficult to ascertain whether the clinical symptoms were due to $B$. hominis or to the other associated pathogens. Therefore, further studies are encouraged to determine the extent of differences among the isoenzyme and DNA hybridisation patterns of more well documented $B$. hominis isolates from symptomatic and asymptomatic persons and to find out if these differences relate to the clinical presentations of the 
hosts reflecting the pathogenic potential of the organism.

We thank Dr R. G. Hibbs and Dr J. R. Campbell for their valuable comments and review of the manuscript. We also thank Mrs Suzette Bassily for typing the manuscript and $\mathrm{Mr} \mathrm{R}$.

\section{References}

1. Jiang J-B, He J-G. Taxonomic status of Blastocystis hominis. Parasitology Today 1993; 9: 2-3.

2. Zierdt $\mathrm{CH}$, Tan $\mathrm{H}$. Ultrastructure and light microscope appearance of Blastocystis hominis in a patient with enteric disease. Z Parasitenkd 1976; 50: 277-283.

3. Boreham PFL, Stenzel DJ. The current status of Blastocystis hominis. Parasitology Today 1993; 9: 251.

4. Hollebeke NL, Mayberry LF. Taxonomic uncertainty and Blastocystosis (Protista: Sarcodina). Parasitology Today 1994; 10: 64

5. Kukosche KG, Necker A, Müller HE. Detection of Blastocystis hominis by direct microscopy and culture. Eur $J$ Clin Microbiol Infect Dis 1990; 9: 305-307.

6. Doyle PW, Helgason MM, Mathias RG, Proctor EM. Epidemiology and pathogenicity of Blastocystis hominis. J Clin Microbiol 1990; 28: 116-121.

7. Shikiya K, Terukina S, Higashionna A. et al. A case report of colitis due to Blastocystis hominis. Gastroenterol Endosc $1989 ; 31$ : 1851-1854.

8. el Masry NA, Bassily S, Farid Z, Aziz AG. Potential clinical significance of Blastocystis hominis in Egypt. Trans Soc Trop Med Hyg 1990; 84: 695.

9. Zierdt CH. Blastocystis hominis. Past and future. Clin Microbiol Rev 1991; 4: 61-79.

10. Lambert M, Gigi J, Bughin C. Persistent diarrhoea and
Pakhtchanian for photographic assistance. This work was supported by the US Naval Medical Research and Development Command, NMC, NCR, Bethesda, MD, USA, Work Unit No. 3M161102BS13.AK.311. The opinions and assertions contained herein are the private ones of the authors and are not to be construed as official or reflecting the views of the US Navy Department, Department of Defense or the US Government.

Blastocystis hominis (Letter). Acta Clin Belq 1992; 47: 129-130.

11. Kukoschke KG, Müller HE. SDS-PAGE and immunological analysis of different axenic Blastocystis hominis strains. $J$ Med Microbiol 1991; 35: 35-39.

12. Boreham PFL, Upcroft JA, Dunn LA. Protein and DNA evidence for two demes of Blastocystis hominis from humans. Int J Parasitol 1992; 22: 49-53.

13. Blagg W, Schloegel EL, Mansour NS, Khalaf GI. New concentration technic for demonstration of protozoa and helminth eggs in feces. Am J Trop Med Hyg 1955; 4: 23-28.

14. Milacek $P$, Vitovec J. Differential staining of cryptosporidia by aniline-carbol-methyl violet and tartrazine in smears from feces and scrapings of intestinal mucosa. Folia Parasitol (Praha) 1986; 32: 50.

15. Zierdt CH, Williams RL. Blastocystis hominis axenic cultivation. Exp Parasitol 1974; 36: 233-243.

16. Laemmli UK. Cleavage of structural proteins during the assembly of the head of bacteriophage $\mathrm{T}_{4}$. Nature 1970 ; 227: 680-685.

17. Kreutzer RD, Christensen HA. Characterization of Leishmania sp. by isoenzyme electrophoresis. Am J Trop Med Hyg 1980; 29: 199-208.

18. Sargeaunt PG, Williams JE. Electrophoretic isoenzyme patterns of the pathogenic and non-pathogenic intestinal amoebae of man. Trans R Soc Trop Med Hyg 1979; 73: 225-227.

19. Daggett PM, Nerad TA. The biochemical identification of vahlkamfiid amoebae. J Protozool 1983; 30: 126-128. 